\title{
MINIMIZING DISPUTES THROUGH THE ADJUSTMENT OF GRIEVANCES
}

\author{
ISADORE KATZ*
}

Labor disputes derive their form and dynamic impetus from the manifold grievances which cause them; any fruitful effort to minimize industrial conflict must be grounded on an understanding of the basic psychological character of grievances. Labor disputes are not comprehensible if judged by standards or norms of behavior usually applied to conflicts between groups contending only for monetary stakes. Efforts to convince workers that a contemplated strike for a wage increase, though it may be ultimately successful in terms of more cents per hour, should not be called because it will take months to make up the lost earnings, have no effect upon them. This is so because the real sources of the propulsive forces of the conflict are not disclosed by such an analysis. Men will undergo great privations and financial loss to overcome oppression. The goals in such a conflict frequently transcend material considerations. In modern industrial disputes much more is at issue than a wage increase even when a wage increase is the declared issue. The grievances which stir workers to take dramatic action are manifestations of profound resentment against a system of industrial organization which not only fails to yield economic security but, more importantly, denies the primacy of the individual in favor of that of the machine, negates his worth, diminishes his self-esteem and corrodes his personality.

Modern industry, preoccupied with mass production techniques, has concentrated upon creating abundance at lower unit costs. In its single-minded devotion to this objective it has excluded the workers from its field of vision except in so far as they service the tools of production. Eager to use machines in place of men, management has displayed callous indifference to the impacts of technological advances upon the men and their families. In pursuit of improved methods, skills have been scientifically analyzed and broken down to their simplest elements. The skilled mechanic has been disjointed, as it were, and each element of the job assigned as a single task to different workers, each of whom is required to conform to the monotonous rhythm of the machine. This steady erosion of.skill has reduced the worker to progressively less important roles in the productive process, making him more easily replaceable until a new piece of equipment may dispense with him entirely.

Management has exhibited little evidence of concern that this process of splitting

- A.B. 1922, LL.B. 1925, Univ, of Pennsylvania. Member of New York and Philadelphiz Bars. General Counsel to Textile Workers Union of America, CIO. Instructor in Logic and Ethics at University of Pennsylvania, 1924-1931. Contributor to legal periodicals. 
skills is frustrating the "instinct of workmanship." The drive for efficiency and the continuous search for the dependable and unvarying performance of the machine has induced an attitude in management which has denied the importance and dignity of the human being. One who is intent upon eliminating men at the machines or who seeks to reduce their contribution to the creative process to an irreducible minimum cannot be expected to be concerned about the welfare of the workers. Their fears and resentments and repressions are not within the orbit of "scientific" industrial engineering. The managerial mind which emerges in men engaged in directing modern production is characterized by imperiousness, sternly ordering the:daily lives of the workers with little concern for their sensibilities and goals. This type of mind is marked by bland indifference and self-assertion. The purchaser of a "hand" to doff the machine or of an "eye" to spot a defect concentrates upon extracting as much of this single activity from the hand or eye as is possible, and to this end time and motion studies are keenly directed. To induce greater effort along narrowly confined channels of work, incentive systems are devised. The systems are coldly calculated in terms of units of energy; upon them complicated wage systems are erected. The ledger sheet of industrial management has no column in which entries can be made of the human cost of this process in terms of suppressed personality, economic insecurity and servility. Nor are provisions made for the active participation by the workers either in the wholeness of the production process or in the planning which so vitally affects them psychologically, socially, and economically.

To the worker this exclusion from the decisional area is an intolerable condition of servility; the erosion of his skill is an inhuman suppression of his urge to create, reducing him in status to a mere adjunct to the machine; the insecurity of his job is a source of continuous uneasiness; the systematic indifference of management to his aspirations, a maddening irritant. The indifference of the manager to his human machines derives from no inherent malice, but solely from the fact that the steady advance of industrial efficiency requires as many replaceable parts in the engine as possible. That the part may be human rather than mechanical has little apparent relevance to the demands of efficient operations.

Life in the plant contradicts all precepts underlying democratic processes in political life. In the shop the worker's worthlessness is impressed upon him at every turn. No use is made of his whole being. No demand is made on his capabilities beyond a few rudimentary motions. His intelligence is rarely challenged. No one calls upon him to participate in the formulation of governing decisions or policies, though he must execute them. This contradiction between the ideals of democracy and reality in industry is overpowering. This tyranny of industrial organization induces frustration, fear, anger and hostility. It is naked power not based on assent, endured because of economic insecurity-but endured only until such time as it can be overcome by the accumulation of countervailing power. 
The aggressive worker singly challenging such a way of industrial life would be quickly discharged; but workers learned early that their individual impotence could be transmuted into power by combination. The emergence of the labor union was a social reflex in response to an inhuman institution. It made its appearance because of the natural coherence of persons similarly situated, who have shared the same experiences. Its members gain sympathetic understanding and warmth from each other. They share jointly the sentiment of animosity toward the managerial autocracy which acts on the ethic that it is more important to produce than to advance the well-being of the workers. All are frustrated in their search for economic security and status. All have the same yearning for liberation and are joined in a common endeavor to achieve freedom.

The worker's sense of grievance is deep-seated in his scarred ego-scarred directly, or through precept, by swift decree condemning the rebel to the hunger, misery and other ravishments of joblessness. So the union is formed to compel management to share governing power with the workers. Each worker seeks to participate in the planning of his own life or in the decisions which affect him, and the labor union is the institution which enables him to do so. It is his creation, moulded and directed by him, or at least energized by his desires. In it he finds sympathy and self-expression. In it he plans action to restore himself and his fellows to respectable status. In its councils he participates in plans devoted to his well-being. Through it he envisions the taming of managerial tyranny, the rebuilding of his self-confidence, and the fulfillment of his demands for respect. He looks to it alone for relief from economic insecurity, for no other social or economic organization within the industrial society concerns itself with his deep-felt wants. As the group achieves power, he shares in its success. The labor union engages his deepest loyalties, for it marks out a path along which he can walk with his fellows with head high, content that he counts, that his voice is heeded, and that his interests are preserved and protected.

It is natural that any assault upon this organization should be viewed by the worker as a direct attack upon each member's personality, not alone as an attack on his economic bargaining position. The discriminatory discharge, the blacklist, the yellow-dog contract, and the company-dominated union were all recognized by workers as undisguised means ruthlessly applied by management to perpetuate their state of individual helplessness. Almost fanatical intensity marks the struggle to resist managerial efforts to bring about the disintegration of the group.

This brief analysis will suffice to show the powerful psychological forces which charge the groups engaged in industrial conflict. The grievances which give peculiar virulence to industrial disputes are those that are pervaded by a sense of individual oppression or which grow out of fear of the destruction of the organism devoted to the worker's interests. The answer to labor disputes will continue to elude us unless in the search for it these fundamental truths are kept dominant. To mini- 
mize labor disputes we must unequivocally reconstruct the form of industrial organizations so as to preserve the integrity of the individual and to provide a special bilateral form of industrial government.

To accomplish this there must be: (I) full and complete acceptance of the labor union as the instrument of a participation in industry by the workers which will not only be tolerated but will be welcomed by management; and (2) a system of daily industrial government in which each worker will be accorded those civil rights in his place of work that will assure not only the right to petition for redress but also the adjustment of his grievances. These two conditions are basic to industrial peace and the process called collective bargaining. The provisions governing grievance procedures in collective bargaining agreements are vital governmental processes which fulfill both conditions. Since the meaning and operation of the second condition only are within the scope of this paper, it alone will be discussed, with the understanding that the first is a prerequisite.

Because of its importance, the procedure for adjusting grievances must be wiscly constructed and its basic integrity preserved in operation. It must conform to the basic nature of the union and the psychological needs of the workers. Care must be taken that it does not serve, as so many grievance procedures have served, as a new means for attacks upon the union nor as an excuse for excluding, by means of statues of limitations, the very grievances it was intended to air. "A proper handing of such questions is a major part of the industrial relations problem of making collective bargaining work. Collective bargaining is not confined to the making of an agreement once a year. It is also a day-to-day process and, on this score, the grievance procedure plays a highly important role." ${ }^{1}$ The process of adjusting grievances is daily confirmation of the right of the workers to participate in directing the course of their lives. It is thus the core of industrial democracy, having been created by the legislative process engaged in by representatives of both parties to the collective-bargaining relationship. The mere establishment of the grievance procedure is concrete and tangible evidence to the worker that management is sharing power and control with him through the union. It is one token of his liberation. Too little recognition has been given by management to this symbolic nature of the grievance process.

The reluctance of management to appreciate the implications of the process of adjusting grievances is often revealed at the very inception of collective bargaining, during the debates over the scope and form of the grievance machinery. This reluctance is disclosed by management's direct or subtle efforts to post the agreement with "no trespass" signs to protect previous title to the domain it calls "management prerogatives." The meaning of such bargaining is not lost on the union and the workers; it gives rise to the tension that always appears when status, already inferior, is in jeopardy. The difficulty is that management fears the end of its exclusive

${ }^{1}$ Chrysler Corp., 10 WAR LAB. Rep. 551, 554 (1943). 
reign and the beginning of a relationship which marks the passing of individual bargaining in the plant. It fears that the individual has now become an integral part of a group and, as in all forms of government, the will of the group, not that of each individual, must prevail. It fears, in short, the transmutation of an item in its cost account into a problem of human relations.

The rules and regulations evolved by collective bargaining represent the current common judgment of the union and management on matters which experience has shown to affect all of the workers. This new form of authority, expressed in the terms of the collective agreement, commands respect and must receive it precisely because it is a product of the democratic process. Neither management, nor the union, nor any individual may violate its formal declarations. The difficulties are enchanced by management's fears that the union and its members are covertly seeking to intrude themselves into all segments of its affairs. It views the grievance procedure as a mere device with which the union will seek to obstruct the efficient operation of the plant. These fears are completely unjustified when viewed in the light of the development of collective bargaining in any industry. They are contradicted in every industry where the collective relation has matured.

Experience has demonstrated over and over again that the emotional intensity of labor disputes is measurably reduced by the institution of a grievance procedure. The urgency of installation of machinery for the adjustment of grievances was clearly seen during the course of World War II by the National War Labor Board, which unanimously adopted the following statement by Chairman William H. Davis on July I, 1943:" "The experience of the National War Labor Board in the administration of the no-strike, no-lockout agreement has shown conclusively that proper grievance procedures under collective bargaining agreements have: $(x)$ Prevented abuse of the no-strike, no-lockout agreement. (2) Removed obstacles to high morale and maximum production. (3) Preserved collective bargaining as a basic democratic institution in the total war effort." It is evident that the therapeutic value of the grievance procedure is so great that even during the greatest war in history, when workers were imbued with exalting loyalities, its absence was an obstacle to high morale and maximum production.

We may turn now to a consideration of those structural elements of the grievance procedure which will provide the machinery for the attainment of, its objectives.

I. The grievance procedure must be consistent with the system of collectivebargaining relations.

There cannot be individual bargaining concurrently with collective bargaining on any matter which concerns the relations between management and employees. If management demands that the individual worker shall have the right to present his grievances for adjustment independently of the union, it thereby reveals that it has not fully accepted the collective-bargaining relationship. To the union this

N. Y. Times, July 1, 1943, p. II, col. I. 
is a patent indication that management seeks a return to individual relations and that the struggle for recognition is not over. At once the atmosphere becomes charged with the tensions of an organism on guard. Instead of enjoying the relaxation of the secure, the members of the group are wary of every proposed adjustment, scrutinizing it with meticulous care to determine whether it is an effort to lure the individual by favoritism and to dissolve his loyalty to the group by discriminatory settlement. If an individual can secure a speedy and favorable settlement without recourse to the union, or if new difficulties arise when the union intervenes, the lesson is clear. So long as this contest over the loyalty of the individual exists, the field is tense with an uneasiness never conducive to calm deliberations. Insistence by management upon protecting the right of individuals to present grievances is viewed as a belated concern for the personality of the worker and as hostile to the group existence.

In argument over this point management seeks support in the proviso to section 9(a) of the National Labor Relations $\mathrm{Act}^{3}$ which declares that the requirement that the employer bargain collectively with the duly designated agency shall not prevent an employee, or a group of employees, from presenting grievances to the employer. During the early years of that Act, the apparent contradiction between effective collective bargaining and this proviso was seized upon by charlatan industrial relations advisers who peddled their services to industry with the promise that under legal cover of this clause they would break the union without exposing the employer to the penalties of the law. Employers who utilized such services were seeking another field on which to fight the battle which the National Labor Relations Act had declared should not be fought again. Collective bargaining in such plants remained in a state of arrested development marked by reciprocal belligerence. Manifestly, in such an atmosphere grievances are grossly distorted and the adjustment process is directed, not at treating the source of the complaint nor at reaching a tolerable accommodation, but at the collateral issue of union security. Thus, instead of minimizing disputes, this parallelism, by irritating the deeper layers of personal insecurity which led to the formation of the group, infused each grievance with the virus of hostility and altered its character.

The National War Labor Board was fully aware of the dangers inherent in such hybrid systems, but because of the exigencies of the war it compromised the issue and evolved a procedure whereby the aggrieved individual could make the choice himself at the first step whether to present his own grievance, either alone or accompanied by the union steward. ${ }^{4}$ Obviously this device does not dissolve the tensions which arise each time an individual chooses to proceed on his own and secure an adjustment which, though satisfactory to him, may constitute a variation of the agreement or run counter to the group interests. Even the supervisor may be unaware of all the implications of an individual adjustment.

49 STAT. 453 (1935), 29 U. S. C. 5159 (a) (1940).

- Aluminum Co. of America, 12 WAR LAB. REP. 446, 454 (rig43). 
The National Labor Relations Board, on the other hand, was compelled by an adverse decision ${ }^{5}$ to come to grips with this problem. Its conclusions are set forth fully in the Hughes Tool Company case," in which it held that the company had been guilty of a violation of section $8(5)$ of the Act "by adjusting grievances of individual employees without affording the union as exclusive bargaining representative the opportunity to negotiate respecting their disposition." The board held that section 9(a) of the Act means that individuals and groups are permitted "to present grievances to their employer" by appearing at every stage of the grievance procedure but that the exclusive representative

$\ldots$ is entitled to be present and negotiate at every stage concerning the disposition to be made of the grievance. If, at any level of the established grievance procedure, there is an agreement between the employer, the exclusive representative, and the individual or group, disposition of the grievance is thereby achieved. Failing agreement of all three parties, any dissatisfied party may carry the grievance through subsequent machinery until the established procedure is exhausted.

This reconciliation of the right of the individual with the paramount right of the bargaining agency has the virtue of preserving the industrial governmental power as well as the opportunity for individual self-expression. It thus accords with the two prerequisites for minimizing labor disputes.

2. The grievance procedure, being governmental in nature, must possess stability and permanence.

The essential qualities of stability and permanence are imparted to the grievance procedure by establishing a clearly defined channel through which grievances may be processed. The channel leads from the worker or the aggrieved group through several steps, each superior to the preceding one by a significant increment of adjusting power, to the final authority. At each stage in the procedure the grievance is jointly examined and appraised by representatives of the union and representatives of management. The representatives of the union are elected by the workers or are appointed to positions at the higher levels by their duly elected officers. Those employees who are elected to act at the initial stage are usually called stewards. At the second stage the representative may be a group, representing a larger operating division, composed of several stewards or a special shop committee. The union usually establishes levels in its own organization as counterparts to the levels of supervision.

In erecting this structure it is important that not too many stages be created, for this militates against prompt disposition of the grievances. Few agreements permit more than five levels; but the number of steps will vary, depending upon the internal organization of both the employer and the union. No fixed pattern

${ }^{5}$ N. L. R. B. v. North American Aviation, Inc., 136 FED. (2d) 898 (C. C. A. gth, 1943).

- 56 N. L. R. B. $98 \mathrm{I}$ (1944), aff'd. on this point in Hughes Tool Co. v. N. L. R. B., I47 Fed. (2d) 69 (C.C.A. 5th 1945), indirectly approved by the Supreme Court in Elgin, J. \& E. Ry. v. Burley, 325 U. S. 7II (1945). 
will serve all conditions. Obviously one form will be assumed where a single small employer is involved and a more complex form where an association of employers is in the collective relationship. Also the form will differ to the extent that the union employs business representatives or other paid agents, and at the step at which they participate. Similarly, the existence of an industrial relations division in management will affect the structure. In short, the structure must be designed to meet the special circumstances of the parties to the agreement.

The significant point, however, is that by the very act of marking out the course of a grievance and designating and electing personnel to administer it, the procedure is presented to the workers as a construct of permanence and stability, and thus induces confidence in its efficacy. To achieve further assurance of continuity, the employees who are stewards or committeemen participating in the process are placed at the top of the seniority list.

3. The procedure must be swift as well as sure.

Having planned the grievance procedure on an ascending scale in space, as it were, it is imperative that the parties make it certain in time as well. The workers must be assured that their grievances will move along. Delays in consideration or decision can drain the process of all confidence. Such delays, unwarranted by the complexity of the problem or unsatisfactorily explained, stir the inner anxieties of the worker that the management still does not take him seriously. Delays may then transmute a simple grievance into a serious threat to the relation by calling up the ever-present fear of being relegated to the status of an inferior whose complaints are not worthy of attention:

One of the chief causes of labor unrest in many industries is the failure of the representatives of the company and of the union to settle grievances with dispatch. Although a particular grievance may appear to be a minor and insignificant matter when viewed from the standpoint of the totality of plant-operation problems, nevertheless to the individual employees involved in the grievance it is a matter of major concern. If a few employees develop a feeling that a consideration of their grievance is being stalled with resulting injustice to them, their fellow employees naturally become fearful that they may receive the same treatment, with the result that very soon a wave of distrust and dissatisfaction in regard to the handling of grievances sweeps the plant. This negative attitude toward grievances spreads to other relationships between the company and its employees, with the consequence that labor morale is injured and maximum production affected detrimentally. ${ }^{7}$

A properly designed grievance procedure avoids such consequences by fixing the time limit for consideration by management at each stage. Such time limits may be extended by mutual assent. It then becomes a matter of right for the union to move on to the next step if a satisfactory adjustment is not reached. Some agreements do not fix the time limits between steps but declare an over-all time limit from the inception of the grievance to the submission to arbitration, within which

\footnotetext{
'General Chemical Co., 3 WAR LAB. ReP. 387,392 (1942).
} 
all the steps must be traversed. Some agreements fix certain days when grievances which have not been adjusted at the lower levels will be taken up by officials with greater authority. No formula can be induced from the practices established by the innumerable agreements in effect. Each collective relation must establish the time limits for managerial consideration which best suit its special circumstances. The vital point is that there must be an assurance of flow of the grievance, with the unchallenged right in the union to carry the grievance forward.

Care must be taken that these time intervals are not converted into dams in the channel, analagous to statutes of limitations in the law. Thus many employers seek to provide that unless the grievance is presented or appealed within the specified time limits, the right to further consideration is foreclosed. A grievance procedure so perverted is obviously designed to keep the management free from stale claims and to penalize the tardy. Whatever may be said in favor of such a penalty system, its vice is that it leaves the grievance unsettled whereas the purpose of the procedure is to adjust, not exclude, grievances.

\section{The grievance channel must be deeply dug to receive all complaints.}

Grievances are complex reactions by workers to the interplay of psychological, social, and economic forces. A proper grievance procedure will be so designed that it will carry all grievances. Yet, in the early stages of the collective relation, management's bargainers tend to be concerned with preventing the adjustment of all but a restricted class of grievances. The grievances they would consider are only those which involve the interpretation and application of the terms of the agreement. This limitation misses the entire point of the grievance procedure and its office in the collective relation. The error derives from failure to appreciate the multi-faceted nature of the collectively bargained agreement.

The collective bargaining agreement is at once a business compact, a code of relations and a treaty of peace. ${ }^{8}$ As an economic accord it sets forth the terms which will govern hiring, work and pay. Normally it is not a contract of employment. As a peace pact it assures against strikes and lockouts. As a code of relations it seeks to create a system of government through the processes of which grievances are resolved, understanding achieved, a line of communication opened between management and employees, and a self-disciplining labor force secured.

The collective agreement is thus a different kind of document from the commercial agreement. The ordinary contract does not partake of the nature of governmental systems; the adjustment clause sometimes incorporated in it serves merely to provide a substitute for a court to resolve disputes over interpretations of the other contract terms which define with care the boundaries of a limited relation between the parties. Thus it is merely ancillary to the other terms of the contract.

${ }^{8}$ Cf. J. I. Case Co. v. N. L. R. B., 32 I U. S. 332, 334-339 (1943); Gregory, The Enforcement of Collective Labor Agreements by Arbitration, 13 U. of CHI. L. Rev. 445, 446-450 (1946). 
In the collective agreement, on the other hand, the grievance procedure is a "system of government" which exists independently of the other clauses of the dgreement.

The narrow view that a complaint need not be considered unless it involves the interpretation or application of the provisions of the agreement is the least qesirable approach to the objective of adjusting grievances. It is not only at odds with the ultimate goal of developing a harmonious and amicable relation in which each worker feels that he is a vital and worthy part, but it proceeds on the erroneous assumption that the relation is capable of precise definition in the contract. It predicates a static relationship in which every point of contact between the contracting parties can be fully reflected in words. Though this may be true of commercial relationships in which the only interest one party has in the other is the article bought or sold, the premises leased or sold, or the money earned or lent, it is not true of the dynamic relation between management and labor. Here the relationship is a multifarious web made up of economic, social and psychological strands inextricably interwoven yet continuously changing in pattern. This community is affected by changes in population, outside competitive forces, outside community activities, changes in production techniques, scientific discoveries, market conditions, internal group relations, and a host of other unpredictable events necessitating quick accommodations-in short, it is a dynamic field of adversary and co-operative group relations. The contingencies in such a relationship can no more be set forth in a contract than can the contingencies of the marital relation. Both defy definition.

Any effort thus to limit the scope of the grievance procedure to the interpretation and application of the provisions of the agreement presupposes that the agreement's provisions can be made so clear and precise as to rule future developments not contemplated by the parties. Such a collective agreement has never been drawn. If it were drawn it would be a particularized code of such length as to destroy its utility. The drafting of it would keep the parties at the bargaining table engaged in interminable exercises in semantics. Such an agreement, if it were ever completed, would serve merely as a vehicle for endless disputes over the meanings to be attached to each phrase. Instead of settling grievances by ameliorating the conditions which nourish them, the parties would be engaged in conflicts over words. The dynamics of the relation preclude such an agreement. Even legislative bodies of political government, when confronted with the necessities of enacting law to govern a kinetic field of action, turn to the administrative process to deal with unanticipated developments.

That collective bargaining agreements cannot and do not cover every event was recognized by the National Labor Relations Board when it pointed out that "any adjustment of a grievance constitutes, if the subject matter is dealt with in the agreement, an interpretation and.application of the contract, or, if the subject matter is not dealt with in the contract, bargaining respecting a condition of employment."

- Hughes Tool Co., 56 N. L. R. B. 981,982 (1944). 
The Railway Labor Act draws a significant distinction between grievances and disputes growing out of the interpretation or application of the agreement. It declares that the purpose of the Act is "to provide for prompt and orderly settlement of all disputes growing out of grievances or out of the interpretation or application of agreements covering rates of pay, rules or working conditions."

The unwise demand that the complaints of the workers must come within particular categories described in the various contract headings recalls the procedural intricacies of the early common law, when a cause of action had to fit the rigid requirements of the available writs. If the cause of action could not be made to meet the technical requirements of the writ, the doors to the courts of justice were not opened. How this denial of process affected social and economic relations in those days is not fully recorded, but we do know that even the common law had to be augmented by equity jurisprudence because of the need to afford means for the adjustment of disputes. In the industrial community we know at the very outset of bargaining that grievances will arise because of occurrences not envisaged by the negotiators and that they cannot be exorcised by pronouncing them out of contract bounds. All grievances, whether real or fancied, reflect discontent and affect production and should be settled. Grievances which are banned find expression in reduced morale, or have the curious trait of assuming the guise of admissible grievances. This is well known to all production men. The excluded and therefore unsettled grievance has the annoying characteristic of making itself known through a drop in efficiency, absenteeism, slowdown, controlled production, quit or turnover. These have always been symptoms of protest. Obviously, the grievance procedure is installed in a plant not to seal up avenues of expression and protest but to open up paths to adjustment.

The sense of injustice of aggrieved workers runs deeply to the very center of their being, and unless allayed quickly will be converted into hate and hostility leading directly to the flaming labor dispute-a result the grievance procedure is designed to avoid.

The grievance procedure furnishes a means of orderly life in the mill. Thus the grievance procedure is not merely the core of the agreement, it is the mechanism whereby industry accommodates itself to the inner drives of working beings. This goes far beyond the confines of the contract clauses and takes account of the whole gamut of human aspirations and fears. It serves as an outlet for the aggrieved worker and at the same time keeps management in close touch with the tone and temper of the relationships in the plant. It reveals to management the reactions of the individuals and the code of behavior of the group of which they are a part. The knowledge thus gained is of utmost importance to the policy makers on both sides. To block up this index of plant morale is not the way to minimize labor disputes but rather the way to remain ignorant of their physiology.

29 48 STAT. 1186 (1934), 45 U. S. C. SI5Ia(5) (1940). 
5. Grievances should be presented in writing at some stage beyond the initial step.

Unions as well as management usually agree that a grievance should be presented in writing, but not at the first step, where informality should prevail. If, however, it must be carried further, good administration requires that the grievance be set forth in written form. This is desirable for several cogent reasons, the most important of which is that after the initial discussion the real basis for the grievance may have been disclosed. The written complaint establishes a record of the grievance, its nature, the date of its disposition, and the manner of adjustment. Such records can be of inestimable value both to the union and the management in furnishing data from which general conclusions can be drawn and broad measures taken to treat conditions which have been chronic breeders of discontent. They furnish as well an opportunity for study of the grievances to discover the patterns into which they fall. Such records can be used as source material for much-needed studies by industrial psychologists.

It must be understood, however, that the writing is not the grievance. It should not be viewed as a pleading at common law, where the case falls if it is ineptly set forth. In short, the writing should be the point from which the parties begin in their search for the cause of the dissatisfaction, irrespective of the direction indicated in the writing.

6. The grievance procedure must provide an end point at which the grievance is settled and a binding decision rendered.

This is an obvious ingredient of a proper grievance procedure. Unless there is assurance that a complaint will terminate in a final decision, resort to the grievance procedure is meaningless and workers will turn from this way of seeking relief to more direct methods. Some few agreements provide an end point at the highest level of management. The difficulty with this prospect is that it really allows management, against whom the complaint is directed, to decide the complaint. To be sure, top officials of management may not hesitate to overrule the lower levels of supervision in minor cases, and indeed may welcome the opportunity of correcting bad practices brought to their attention through the grievance procedure; but this will not happen when the complaint involves a change inaugurated by the top official. In such cases the accused is also the judge. The futility of appeal to him is clear.

The grievance procedure must provide for final decision by an impartial person whose decision shall be accepted as final. This element gives a sense of security to the parties. It reassures the workers and their representatives that the adjustment of the grievance is not entirely in the hands of the employer. By its 'very presence in the agreement it disposes the parties to reach an accord themselves without resort to it. This is the overwhelming verdict of experience. ${ }^{11}$

${ }^{21}$ For further discussion of this aspect of the grievance procedure, see Frey, The Logic of Collective Bargaining and Arbitration, infra. 
There are additional, though subsidiary, requirements of a well-balanced grievance procedure, such as the obligation of management to pay the stewards and members of the grievance committee for time lost while adjusting grievances, and to permit a business agent of the union to enter the plant for the purpose of investigating complaints and generally determining whether conditions in the plant conform to the agreement's terms. Both requirements come within the concept of "policing the agreement." Management should pay for time lost because employees who handle grievances, whether they be supervisors or production employees, are working as much in the interest of efficient operations as the maintenance crew who service and repair the plant equipment. Management should also permit a union business agent to have access to the plant during working hours, on proper notice to the company, because the expertise of the business agent in detecting likely trouble spots is invaluable. His experience and close relation to the men who are aggrieved, or in whom a grievance is forming, enables him to appraise its nature and, at times, to diagnose the source more swiftly than the men themselves. He is then in position to bring the matter to the attention of management before it develops into serious trouble. Manifestly, if he has the right to participate in the adjustment process at some stage, he must be accorded the right to view the scene. Because of these considerations the National War' Labor Board, when called upon to decide a dispute over this phase of grievance procedure, has invariably ruled in favor of access to the plant by accredited non-employee union agents and officers. ${ }^{12}$

The incorporation into the collective agreement of a grievance procedure, properly designed according to the structural principles outlined here, works a reorientation of the attitudes of all parties. But collective bargaining does not end with the signing of the agreement. In a real sense, it is but the point of departure from which the parties may proceed to establish a sound relationship. The assurance of continous harmonious relationships thereafter depends upon the day-to-day operation. The success or failure of the grievance procedure in achieving mutual understanding depends upon the intelligence with which the parties apply it to the boundless variety of complaints. If the parties will accept the complaint as a symptom of discontent, and give it hospitable reception, it will shortly appear that specific actions and conditions evoke similar reactions in worker as well as supervisor. Thus patterns of human conduct will be traced which will suggest specific measures of prevention as well as treatment.

The compilation and appraisal of experience under grievance procedures have resulted in better understanding of the larger problems, and that understanding has, in turn, led to avenues through which an overloaded grievance machinery may be relieved of some of its burdens. The parties soon realize that types of grievances may be anticipated, and are consequently enabled, by the adoption of new contract provisions and other means, to translate their experience into more permanent and

${ }^{28}$ Lane Cotton Mills Co., 7 WAR LAB. REP. 281, 288 (1943). 
satisfactory procedures to deal with specific causes of discontent, thus obviating in many instances the necessity for resort to the grievance procedure. For example, it is well known that every challenged discharge of a worker is difficult of reversal, irrespective of the justice of the complaint, because of the reluctance of management to reverse a disciplinary measure. Questions of prestige command priority over those of justice. Recognition of this obstruction in discharge cases, coupled with a desire to do justice to the discharged worker, has led some unions and employers to institute a system of "suspension-discharge." Under this procedure the employee is not peremptorily discharged but receives instead a notice of suspension-discharge which means that unless a protest is lodged with the employer within a specified number of days after the notice, during which period the worker may or may not be out of work, the suspension-discharge will ripen into final discharge. This technique appears to work well where it is in operation since it dispels the atmosphere of irrevocability which surrounds a discharge. If a protest is filed, the discharge is arrested at the point of suspension while the case is reviewed. Thus management at a higher level finds it possible to consider the merits of the case unencumbered by the retarding influence of prestige questions.

Similar results may be achieved in a more difficult field-that of work changes. Labor disputes growing out of changes in methods of production or technology are the most difficult of adjustment because they touch the most sensitive layers of the behavior patterns of workers. Changes disturb fixed working habits and arouse fear of the unknown and fears of diminished earnings, dilution of skill, or abolition of the job itself. Much progress can be made in overcoming this resistance if the employer will proceed to persuade the employees to assent by giving prior notice to them of the change and, through consultation, apprising them of the necessity for or desirability of the change, its nature and extent, and its effects upon their earnings, effort, and job security. Where changes have been preceded by these preliminaries, fears have been dispelled and assent more easily secured. As a result, measures in the nature of preventive hygiene have been inaugurated in many plants. They require that all technólogical changes be preceded by notice and disclosure of all relevant data and of the full program. Adequate assurances are given to protect the earnings of the employees and to provide a share for them of the savings resulting from the change. In return, the workers have agreed to a trial period during which they seek to accommodate themselves to the change. Thereafter, grievances may be filed and are processed under the established grievance procedure.

Similarly, grievances over rates of pay have led to co-operative analyses of wage scales and the formulation of a balanced wage structure in which comparable skills are equitably rewarded. Again, losses in earnings of piece or incentive workers, a continuous source of anger and grievance, has led to the adoption of a general principle whereby a worker is guaranteed a daily minimum or one which assures the worker's pay when time is lost because of faulty materials, machine breakage, 
or other conditions beyond his control. Likewise, management has in many mills recognized the injustice of sending a worker home because of lack of work and has provided that an employee who reports for work on his regular shift, not having been given reasonable notice not to report, is entitled to receive four hours' reporting pay. These are but a few of the general rules which have been evolved to protect the worker and thus diminish the areas which nurture grievances.

These examples illustrate that in modern industry we are dealing with the entire complex of human behavior. Two basic prerequisites for the minimizing of labor disputes through the use of adjustment machinery have been postulated here. The grievance procedure which has been suggested is based upon a recognition of the nature of the labor union and upon the necessity for the establishment of a stable system of reviewable civil rights for workers in industry. These are most powerful purgatives of industrial unrest. The grievance procedure suggested takes full account of the interpenetrating relationships in industry where men, whose interests are both adverse and conjoined, live in close association. Management, which has directed the operation of the machine, must now turn its attention to the human problems in industry. To the extent that management takes cognizance of, and intelligently deals with, the individual employee and the group which he has formed to advance, preserve, and protect his interests, democracy, absent too long from the industrial life of our society, will develop and will relieve those tensions which are such 2 frequent source of industrial strife. 